\title{
BŁOGOSŁAWIEŃSTWO JAKUBA (RDZ 49,1-28) W INTERPRETACJI TARGUMICZNEJ
}

Księga Rodzaju 49 przedstawia scenę, która rozgrywa się przy łożu śmierci patriarchy Jakuba. W obliczu śmierci Jakub wzywa do siebie wszystkich swoich synów, aby wysłuchali jego słów pożegnania. Patriarcha zwraca się indywidualnie do każdego z nich. Dokument ten (1-28) jest pierwszym wyraźnym przykładem poezji hebrajskiej w Pięcioksięgu. Stanowi połączenie trzech gatunków literackich: błogosławieństwa na łożu śmierci; ${ }^{1}$ mowy pożegnalnej ${ }^{2}$ oraz poematu o charakterze plemiennym. ${ }^{3}$ Chociaż kompozycja tych wersetów jest zgodna z ogólnymi wzorcami, które charakteryzują poezję biblijną, istnieje wiele niepewności, jeśli chodzi o znaczenie użytych tu wyrażeń, a także aluzji. Rozdział ten jest określany jako najtrudniejszy fragment Księgi Rodzaju. ${ }^{4}$

Powszechnie rozdział 49 jest znany jako „błogosławieństwo Jakuba". Jednak to określenie nie jest ścisłe, ponieważ wiersze zawierają

\footnotetext{
1 Znane już z wcześniejszych narracji o patriarchach (Rdz 27,27nn., 28,1-4 i $39 n$.).

2 Występuje w późniejszych tekstach: Joz 23n. i 1 Krl 2,1-9.

3 Pwt 33 i Sdz 5.

4 Na złożoność tego fragmentu wskazywali już średniowieczni egzegeci żydowscy. Byli oni również świadomi tego, że niektóre z aforyzmów mogą się odnosić do przeszłości, konkretnie do czynów przodka, od którego dane plemię pochodzi, łącznie z jego imieniem, podczas gdy inne były aluzjami do historii plemion z czasów o wiele późniejszych. Komentatorzy średniowieczni uznawali także te wypowiedzi za prorocze, nie starając się szukać w nich próby włączenia późniejszej rzeczywistości, jak to czynią studia współczesne.
} 
materiał o bardzo mieszanym charakterze. ${ }^{5}$ Oryginalnie kolekcja aforyzmów dotycząca kolejnych szczepów nie tworzyła jednego tekstu. Poszczególne tradycje plemienne osadzone w poezji istniały zapewne niezależne od siebie i odnosiły się do odrębnych historii. Na te różnorodne materiały nałożono zewnętrzną jedność, która nadała spójność i znaczenie całości. Poemat jest zamknięty w ramach prozy, w której znajdują się wzmianki o śmierci patriarchy, włączone w narrację o Józefie. W ten sposób autor biblijny odzwierciedla popularną wiarę we wspólne pochodzenie plemion i podstawową jedność narodu Izraela. ${ }^{6}$

Jednym ze świadectw wczesnej egzegezy żydowskiej są targumy, czyli aramejskie przekłady Biblii Hebrajskiej. Targum towarzyszył tekstowi hebrajskiemu i był przekazywany ustnie, co powodowało jego nieustanną zmianę; ${ }^{7}$ w końcu został jednak spisany. ${ }^{8}$ Oprócz przekładu zawierał także parafrazę, uzupełnienia tekstu i aktualizacje, które wiernym w synagodze lub w użytku prywatnym pomagały w rozważaniach nad tekstem. Mogły być też wykorzystywane w bet ha-midrasz, to jest rabinicznych szkołach egzegetycznych. Wyniki

5 Są tam błogosławieństwa i przekleństwa, wyrazy nieufności i uwielbienia, a także obserwacje geograficzne i historyczne. Z tego względu niektórzy uczeni proponują inne tytuły, które lepiej pasują do kontekstu, np. Ostatnie słowa Jakuba lub Testament Jakuba; N. M. S a r n a, Genesis, The JPS Torah Commentary, Jewish Publication Society, Philadelphia 1989, s. 331.

6 Tamże.

7 W trakcie odczytywania tekst hebrajski powinna czytać jedna osoba a przekład inna. Rabini wprowadzili również dwa odmienne sposoby recytacji. Czytającemu po hebrajsku nie było wolno spoglądać poza zwój, który trzymał przed sobą, natomiast osoba dokonująca przekładu musiała deklamować z pamięci. Wprowadzenie tych uregulowań zapobiegało powstaniu wrażenia, że targum jest wpisany w Torę. Osobie niepełnoletniej nie było wolno czytać po hebrajsku, mogła ona jednak podobnie jak niewidomy - dokonywać przekładu.

8 Historia powstania targumów aramejskich przekładów Biblii Hebrajskiej jest bardzo złożona. Przyjmuje się, że kiedy one powstają, Biblia Hebrajska była już kompletna, przynajmniej w części Prawa i Proroków. Tradycyjnie początki targumów umieszcza się w czasach powygnaniowych. 
takich badań mogły być następnie przekazywane ludowi zgromadzonemu na modlitwie w synagodze.

Centralne znaczenie Tory w życiu społeczności żydowskiej spowodowało powstanie większej liczby aramejskich wersji tej części Biblii Hebrajskiej. ${ }^{9}$ Warto podkreślić, że przez całe wieki większość Żydów znała Biblię przede wszystkim dzięki jej publicznemu odczytywaniu na głos. W kulcie synagogalnym tylko Torę odczytuje się w całości, zwykle w cyklu całorocznym. Z pozostałych dwóch części kanonu hebrajskiego, to jest Newiim - Proroków i Ketuwim - Pism są czytane tylko fragmenty. Szkoły żydowskie zdecydowanie więcej uwagi poświęcały Torze niż pozostałym dwóm częściom kanonu Biblii Hebrajskiej. O ile poglądy Żydów kształtuje cały TaNaK, o tyle ich Prawo - istota żydowskiej tożsamości i praktyki - opiera się wyłącznie na Torze.

Uczeni w Piśmie uważali, że targum trzeba uznać za organiczną część literatury rabinicznej - biorąc pod uwagę ich cechy charakterystyczne przypominają sposoby objaśniania Biblii (hebr. derasza). Jedynie przy takim podejściu można zrozumieć, dlaczego autorzy targumu z taką swobodą obchodzili się z tekstem biblijnym. Do naszych czasów zachowały się następujące targumy Pięcioksięgu: Targum Onkelosa $(\mathrm{TgO})^{10}$ oraz tzw. targumy palestyńskie, które reprezentuje Kodeks Neofiti 1 (TgN), ${ }^{11}$ Targum Pseudo-Jonatana

9 Na temat aktualnego stanu badań nad targumami do Piecioksięgu, zob. np. P.V.M. F l e s h e r, B. C h i 1 t o n, The Targums: A Critical Introduction, Baylor University, Waco (TX) 2011, s. 69-166.

10 W opinii rabinów babilońskich TgO uchodził za oficjalny targum do Pięcioksięgu. Rabini nazywają go „naszym targumem” (b.Qid.49a). Kiedy w TB pojawia się aramejski przekład jakiegoś urywka z Pięcioksięgu, cytat zawsze odpowiada temu z TgO. Rabini uważali nawet, że jego egzegeza rozstrzyga kluczowe zagadnienie halachiczne. O babilońskich korzeniach TgO świadczy również jego język, ponieważ jego aramejski ma wschodnie formy gramatyczne i słownictwo; P.S. A 1 e $\mathrm{x}$ a $\mathrm{n}$ d e r, Jewish Aramaic Translations of Hebrew Scriptures, w: M. J. M u $1 \mathrm{~d}$ e r, H. S y s 1 in g (red.), Mikra: Text, Translation, Reading and Interpretation of the Hebrew Bible in Ancient Judaism and Early Christianity, CRINT 2:1, Van Gorcum, Assen-Maastricht, Fortress Press, Philadelpia1988, s. 217n.

11 Kodeks Neofiti 1 ukazał się drukiem w 1504 lub 1499 r. Odkryty w Bibliotece Watykańskiej przez A. Diez Macho w 1956 r. 
$($ TgPsJ $),{ }^{12}$ Targumy Fragmentaryczne ${ }^{13}(\mathrm{TgF})$, fragmenty z genizy kairskiej ${ }^{14}$ i tosefot. ${ }^{15}$

Źródła potwierdzają, że targumy miały na celu obszernie wyjaśnić Torę słuchaczom, którzy niewystarczająco znali hebrajski: „I tłumaczy, aby reszta ludu mogła zrozumieć, tak kobiety, jak i dzieci” (m. Soferim 18,5). Taki był w zasadzie cel derasza, to jest wyjaśniania tekstu świętego. Wydaje się więc, że zarówno derasza, jak i targum wywodzą się $\mathrm{z}$ dążenia uczonych, by Tora była wśród ludu bardziej znana i zrozumiała, a także z zamiaru łączenia jej znajomości z tradycją ustnego nauczania. Targumiści odczytywali Biblię jako przekazywaną im i ich współczesnym wiadomość, która powinna pozostać zrozumiała. Z tego też względu starali się skupiać głównie na trudnym i obcym dla swoich odbiorców słownictwie i objaśnieniu go. Ponadto ich refleksja nad tekstem przyczyniała się do wprowadzania nowych elementów. Wśród technik

12 TgPsJ zawiera przekład niemal każdego wiersza Pięcioksięgu. Jest to wyjątkowe dzieło literackie, zupełnie inne od pozostałych targumów Pięcioksięgu. Różni się nie tylko od $\mathrm{TgO}$, ale także od $\mathrm{TgN}$ i TgF oraz od fragmentów z genizy kairskiej, które reprezentują autentycznie palestyńską tradycję targumiczną. Jednak należy zwrócić uwagę, że TgPsJ ma ścisły związek z TgO i z targumami palestyńskimi Pięcioksięgu. Zapisany został w języku aramejskim literackim w dialekcie późno-żydowskim, który łączy w sobie elementy Targumu Onkelosa i targumów palestyńskich. Podkreśla się, że w przekładzie tym znajduje się ok. 1500 uzupełnień, które nie występują w istniejących targumach, chociaż pewne podobieństwo do tego materiału można znaleźć w pismach rabinicznych. Określenie daty powstania targumu jest bardzo trudne. Aktualnie wśród uczonych trwa dyskusja nad datą powstania TgPsJ, jedna grupa uczonych opowiada się za jego pochodzeniem z IV w. (Hayward, Mortensen, i Flesher), natomiast druga za czas powstania wskazuje średniowiecze lub przynajmniej po VII w. (Shinan, Splansky itp.); P.V.M. F l e s h e r, B. C h i l t o n, The Targums: A Critical Introduction, s. 89. Na temat szczegółowej dyskusji nad datacją TgPsJ, zob. tamże, s. 159-166.

13 Określane wcześniej jako Targum Fragmentaryczny zw. też Targumem Jerozolimskim II. Jednak zachowane fragmenty są urywkami różnych rękopisów targumicznych Są to ocalałe fragmenty rękopisów aramejskich przechowywanych w różnych bibliotekach Europy: w Paryżu (TgF P, XV w.), Bibliotece Watykańskiej (TgF V, XIII w.), Norymberdze (TgF N, XIII w.), Lipsku (TgF L, XIII-XIV w.).

14 Są to fragmenty tekstów targumów do Tory z VIII-XIII w. znalezione przez S. Schechtera w 1896 r. w genizie synagogi w Kairze (CG).

15 Tzw. dodatki, które zawierają niektóre średniowieczne manuskrypty. 
translatorskich istotną rolę odgrywała aktualizacja tekstu, która odbywała się na trzech poziomach: historycznym, kulturowym i religijnym.

$\mathrm{Z}$ badań porównawczych nad aramejskimi przekładami Tory wynika, że targumy różnią się między sobą sposobem oddania poszczególnych elementów oryginału. Każdy z nich stara się jednak nie zakłócać narracyjnej płynności wersji hebrajskiej. Metoda ta zakłada świadome zmiany translacyjne polegające albo na uzupełnianiu systemu ,,jeden do jednego", albo na odejściach od niego. Takie osobliwe połączenie wiernego odzwierciedlania hebrajskiego słownictwa z egzegezą pozwala uznać targum za idealny odpowiednik hebrajskiego tekstu źródłowego. Szczególnie często targumy odbiegają od dosłownego znaczenia tekstów biblijnych w wersach poetyckich i profetycznych, które nadają się do eschatologicznych i mesjańskich interpretacji. Jednym z przykładów takiego tłumaczenia są targumiczne wersje Księgi Rodzaju 49. Należy podkreślić, że sam tekst hebrajski Rdz 49 w wielu miejscach jest niejasny, nic więc dziwnego, że wersje starożytne przetłumaczyły go dość swobodnie. ${ }^{16}$

Warto zauważyć, że przekłady aramejskie do Pięcioksięgu zawierają materiał halachiczny, jednak w targumach palestyńskich, czy też $\mathrm{w}$ TgPs $\mathrm{J}^{17}$ można odnaleźć elementy halachiczne, z których wiele stoi w sprzeczności z rozwiązaniami przyjętymi przez rabinów. Podobnie zawartość materiału haggadycznego często odbiega od tego, który znajduje się w pozostałych targumach. Przekazują one liczne, powszechne przekonania, przez przedstawienie materiału $\mathrm{w}$ taki

16 Na temat Rdz 49 w targumach zob. m.in.: Y. K o m lo s h, „Ha-Aggadah betargumê birkat ya 'akob”, Annual of Bar-Ilan University: Studies in Judaica and the Humanities I, Pinkhos Churgin Memorial Volume, Jerusalem, 1963, s. 198nn.; R. S y r é n, The Blessings in the Targums. A Study of the Targumic Interpretation of Genesis 49 and Deuteronomy 33, Åbo 1986; B. G r o s s f e ld, M. A b e r b a c h, Targum Onkelos to Genesis 49, Society of Biblical Literature, Missoula (Mt) 1976; zob. też: B. G r o s fe ld, The Targum Onqelos to Genesis: Translated, with a Critical Introduction, Apparatus, and Notes. Aramaic Bible 6, Del. Glazier, Wilmington 1988, s. 158-173.

17 K. C a th c a r t, M. M a h e r, M. M c N a m a r a (red.), The Aramaic Bible: Targum Pseudo-Jonathan: Genesis I, The Liturgical Press, Collegeville (Mn) 1992. 
sposób, aby zbudować prostych ludzi i zachęcić do przestrzegania zasad religijnych.

W artykule tym zostanie podjęta analiza porównawcza aramejskich przekładów ww. 49, 1-2 i 49,10-12 w kontekście koncepcji eschatologicznych i mesjańskich, a także omówione jedno z błogosławieństw skierowane do plemienia Beniamina na podstawie wersji Targumu Pseudo-Jonatana. ${ }^{18}$

\section{Obraz „końca dni” w targumach do Rdz 49,1-2}

Poetycki fragment Rdz 49 odgrywa kluczową rolę w ogólnej strategii narracji patriarchów, jak również strategii księgi jako całości. Ostatnie słowa Jakuba do jego synów stały się okazją do wyrażenia głównych tematów Księgi Rodzaju. Kluczem do zrozumienia ostatnich słów Jakuba jest odczytanie ich w ramach narracji, którą przedstawiają. Podobnie, jak w tekście masoreckim, w przekładach aramejskich już w ww. 1-2, które są wprowadzeniem do błogosławieństwa Jakuba znajduje się materiał dodatkowy, prezentujący charakterystyczną interpretację tekstu biblijnego.

\section{$\operatorname{Rdz} 49,1-2$}

Przekład tekstu masoreckiego: ${ }^{19}$

${ }^{1} J a k u b$ przywołał swoich synów i powiedział do nich: „Zgromadźcie się, a opowiem wam, co was czeka w czasach późniejszych.

18 Pierwsze wydanie drukowane ukazało się w 1591 r. na podstawie rękopisu, który się jednak nie zachował. Zawiera go również rękopis z XV-XVI w., przechowywany w Bibliotece Brytyjskiej. Od czasów pierwszej publikacji był identyfikowany jako Targum Jeruszalmi (TJ 1). Jednak badania nad językiem Targumu Pseudo-Jonatana wskazały, że nie jest to dialekt palestyńsko-żydowski aramejskiego. Dlatego też uczeni nie zaliczają tego targumu do targumów palestyńskich, a nazwa Targum Jeruszalmi, nie jest już używana. P.V.M. F 1 e s h e r, B. C h i 1 t o n, The Targums: A Critical Introduction, s. 87-89.

19 Pismo Święte Starego i Nowego Testamentu, Biblia Tysiąclecia (BT), Wydawnictwo Pallotinum, Poznań 20015. 


\section{'Zbierzcie się i słuchajcie synowie Jakuba, słuchajcie Izraela, ojca waszego!"}

\section{Wersje targumów przedstawia poniższa tabela.}

\section{$\mathrm{TgO}^{\mathrm{a}}$}

${ }^{1}$ Jakub przywołał swoich synów i rzekł: „Zgromadźcie się, a powiem wam, co was spotka na końcu dni"
$\operatorname{TgN}{ }^{\mathrm{b}}$

${ }^{1}$ Jakub przywołał swoich synów, mówiąc do nich:

„Zgromadźcie się, a ogłoszę wam ukryte tajemnice, utajone końce, nagrody przypisane sprawiedliwym i kary dla złoczyńców oraz jaka będzie szczęśliwość Edenu".

Dwanaście plemion zgromadziło się razem i otoczyło złote łoże, na którym leżał nasz ojciec Jakub, po tym jak koniec został mu objawiony, aby ogłosić im ustalony czas błogosławieństwa i pocieszenia. Jak tylko koniec został mu objawiony, to tajemnica została przed nim zakryta. Oni mieli nadzieję, że oznajmi im ustalony koniec odkupienia i pocieszenia. Jak tylko tajemnica została mu objawiona, to była ukryta przed nim, i jak tylko drzwi zostały dla niego otwarte, to zostały przed nim zamknięte.
TgF P

$\mathrm{Pc}^{\mathrm{c}}$ : A Jakub wezwał swoich synów i rzekł do nich: „Zgromadźcie się, a ukażę wam, co się z wami stanie, udzielenie nagrody sprawiedliwym oraz pomstę, złoczyńcom w czasie, kiedy zbiorą się razem na koniec dni". I objawił im wszystko, co ma się stać w czasach Mesjasza ${ }^{\mathrm{d}}$ Po tym, jak zostało mu to objawione, zostało to przed nim zakryte; i wstał Jakub i im pobłogosławił - każdemu zgodnie z treścią jego błogosławieństwa, jakim pobłogosławił ich.

VNL: ${ }^{e}$ Jakub, nasz ojciec, wezwał swoich synów i rzekł do nich: Zgromadźcie się, a ja pouczę (was), [o] ukrytych ustalonych końcach, zatajonych tajemnicach, udzieleniu nagrody sprawiedliwym i pomsty na złoczyńcach i jakie są bezpieczeństwog Edenu.

Kiedy dwanaście pokoleń Jakuba zebrało się razem wokół złotego łoża, na którym leżał nasz ojciec (Jakub), prosząc, aby dał im końcowe błogosławieństwo i pocieszenie.
TgPsJ

${ }^{1}$ A Jakub wezwał swoich synów i rzekł do nich: „Oczyśćcie się ze swej nieczystości, a ukażę wam rzeczy zakryte i końce nieznane, nagrodę sprawiedliwego i odpłatę niegodziwca, bezpieczeństwo Edenu - oto czym jest".

Dwanaście pokoleń Izraela zgromadziło się razem wokół złotego łoża, na którym leżał; i objawiła mu się chwała Szechina JHWH, lecz zakryty był przed nim czas nadejścia Mesjasza króla; i rzekł wówczas: „Podejdźcie, żebym mógł wam powiedzieć, co wam się przydarzy w dniach ostatecznych". 
$\mathrm{TgO}^{\mathrm{a}}$

$\operatorname{TgN}^{\mathrm{b}}$

Nasz ojciec Jakub odpowiedział i pobłogosławił ich; każdego błogosławił według jego dobrych czynów.
${ }^{2}$ Zbierzcie się i słuchajcie, synowie Jakuba, przyjmijcie pouczenie od Izraela, waszego ojca.
TgF P

TgPsJ

Jak tylko tajemnica była objawiona mu, została zakryta przed nim; jak tylko drzwi zostały otwarte dla niego, zamknęły się przed nim. Nasz Ojciec Jakub odwrócił się i pobłogosławił swoich synów, pobłogosławił ich, każdego według jego dobrych uczynków.

${ }^{2}$ Po tym jak dwanaście plemion Jakuba zgromadziło się razem i otoczyło złote łoże, na którym leżał nasz ojciec Jakub, oni mieli nadzieję, że on objawi im porządek błogosławieństw, lecz to było ukryte przed nim. Nasz ojciec Jakub, odpowiadając, rzekł do nich: „Od Abrahama, ojca mego ojca, powstał nieczysty Izmael oraz wszyscy synowie Keturaha. Od Izaaka, mego ojca, powstał nieczysty Ezaw, mój brat. A ja boję się, że pośród was będzie ktoś, czyje serce będzie podzielone przeciwko swym braciom, aby oddawać kult obcym bóstwom". Dwunastu synów Jakuba odpowiedziało razem, mówiąc: „Posłuchaj nas, nasz ojcze! Pan, nasz Bóg, to jeden Pan".
W manuskryptach PVN ${ }^{2}$ Zbierzcie się i w. 2 odpowiada właściwie słuchajcie, synowie TgN z nieco zmienionymi Jakuba, przyjmijcie wariantami. pouczenie od Izraela, waszego ojca. 
$\operatorname{TgO}^{\mathrm{a}}$

$\operatorname{Tg} \mathbf{N}^{b}$

$\operatorname{TgF} \mathbf{P}$

TgPsJ

Jakub, odpowiadając, rzekł: „Niech Jego imię będzie błogosławione i niechaj chwała Jego królestwa trwa na wieki wieków".

a Przekład własny.

b Przekład polski M. S. W ró b e 1, Targum Neofiti 1. Księga Rodzaju, Tekst aramejski - przekład, Aparat krytyczny - przypisy, Biblia Aramejska I, Wydawnictwo „Gaudium”, Lublin 2014. Por. też tłum. ang. K. C a t h c a r t, M. M a h e r, M. M c N a m a r a (red.), Targum Neofiti 1: Genesis I, The Liturgical Press, Collegeville (Mn) 1992.

c Przekład własny za tekstem aram. w: Comprehensive Aramaic Lexicion, Fragment Targum recension P, Hebrew Union College, Paris 2005.

d Dosł. „w końcu na piętach Mesjasza” = ,ślady Mesjasza”.

e Przekład za tekstem aram. w: Comprehensive Aramaic Lexicion, Fragment Targum recension VNL, MSS Vatican Ebr. 440, Nuernberg and Leipzig B.H. fol. 1, Hebrew Union College 2005.

f Aram. ואני od תני ואני może oznaczać „,opowiedzieć”, „powtórzyć”, „pouczyć”.

g Aram.שלווה-,_,bezpieczeństwo”,,,łatwość”, por.tłum.M. W r ó b e 1-,rozkosze”.

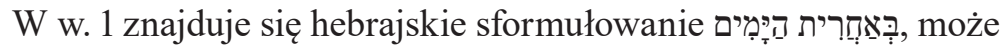
oznaczać „czasy późniejsze”, „w przyszłości” ${ }^{20}$ czy też „dni ostatnie”. ${ }^{21}$ Wyrażenie to pojawia się, oprócz tego miejsca, jeszcze tylko trzy razy w Pięcioksięgu, ${ }^{22}$ natomiast częściej jest używane w księgach

20 Pismo Święte Starego i Nowego Testamentu. Najnowszy przekład z języków oryginalnych z komentarzem (BP), Edycja Świętego Pawła, Częstochowa 2008; Biblia Ekumeniczna to jest Pismo Święte Starego i Nowego Testamentu z księgami deuterokanonicznymi. Przekład ekumeniczny z języków oryginalnych, Towarzystwo Biblijne w Polsce, Warszawa 2007.

${ }_{21}$ Biblia Gdańska (1633). Por. the end of the days, i.e. the latter days, the future, w: D. J. A. C 1 in e s (red.), The Dictionary of Classical Hebrew, t. 1, Sheffield Academic Press; Sheffield Phoenix Press, Sheffield 1993, s. 200.

22 Lb 24,14; Pwt 4,30 i 31,29. 
prorockich. ${ }^{23}$ Zdaniem niektórych uczonych jest to zapowiedź zmian, które będą miały miejsce $\mathrm{w}$ dalekiej przyszłości, natomiast według innych należy do języka prorockiej eschatologii. ${ }^{24}$

W tradycji targumicznej wyrażenie to staje się impulsem do parafrazy, ukazującej eschatologiczne poglądy panujące w ówczesnej społeczności żydowskiej. ${ }^{25}$ Targumy palestyńskie: $\mathrm{TgN}, \mathrm{TgF}$, fragmenty z genizy kairskiej ( $\operatorname{TgC~Z}$ ) oraz Tg PsJ przekazują rozbudowaną parafrazę na temat „końca dni” i tego, co się wtedy wydarzy. Obraz przedstawiony w nich ukazuje rozwój idei eschatologicznych i mesjańskich. ${ }^{26}$ Ta bogata tradycja interpretacyjna zawarta $\mathrm{w}$ targumach palestyńskich i TgPsJ do Rdz 49 powinna być badana nie tylko w rabinicznych źródłach, w których można odnaleźć bezpośrednie paralele, ale też w literaturze apokaliptycznej, szczególnie w Testamentach Dwunastu Patriarchów oraz zwojach z Qumran.

Przekład w. 1 w Targumie Neofiti różni się nieco od Targumu PseudoJonatana i Targumów Fragmentarycznego P. ${ }^{27} \mathrm{TgN}$ prezentuje dłuższy tekst, również w w. 2, a do tego powtarza fragment z w. 1, przechodząc do w. 2 .

W tradycji targumicznej Jakub przystępuje do objawiania „dni ostatecznych”. Wszystkie targumy weryfikują pogląd, że Jakub powinien miał przystąpić do objawiania „dni ostatecznych”, zanim jeszcze otrzymał na to pozwolenie od Boga (por. b.Pes. 56a).

23 Iz 2,2; Jr 23,20; 30,24; 48,47; 49,39; Dn 10,14; Oz 3,5; Mi 4,1.

24 Zob. C. W e s t e r m a n n, A Continental Commentary: Genesis 37-50, Fortres Pres, Minneapolis (Mn) 2002, s. 223.

25 W czasach gdy aramejski był językiem mówionym w Palestynie można zaobserwować duże zainteresowanie spekulacjami związanymi z eschatologią; zob. R. P. G o rd o n, The Targumist as Eschatologists, w: Hebrew Bible and Ancient Versions: Selected Essays of Robert P. Gordon, Society for Old Testament Study, Routledge, Florence Taylor and Francis, London-New York 2016, s. 303-316.

26 Rozbudowane fragmenty można odnaleźć do w. 1 i 18 w przekazie tosefty z genizy kairskiej (TgC FF).

27 Natomiast TgF V jest niemal identyczny z TgN. 
Należy zaznaczyć, że tylko w TgPsJ jest jednak mowa o potrzebie oczyszczenia z nieczystości, które jest konieczne, by przygotować człowieka na objawienie. ${ }^{28}$

O ile TgO tłumaczy hebrajskie wyrażenia przez aramejskie ๆִ רְ יוֹמִָּ - ,na końcu dni”, to targumy palestyńskie wprowadzają dodatkowy opis, a szczególnie TgN, który wymienia najwięcej terminów, charakteryzujących ten czas:

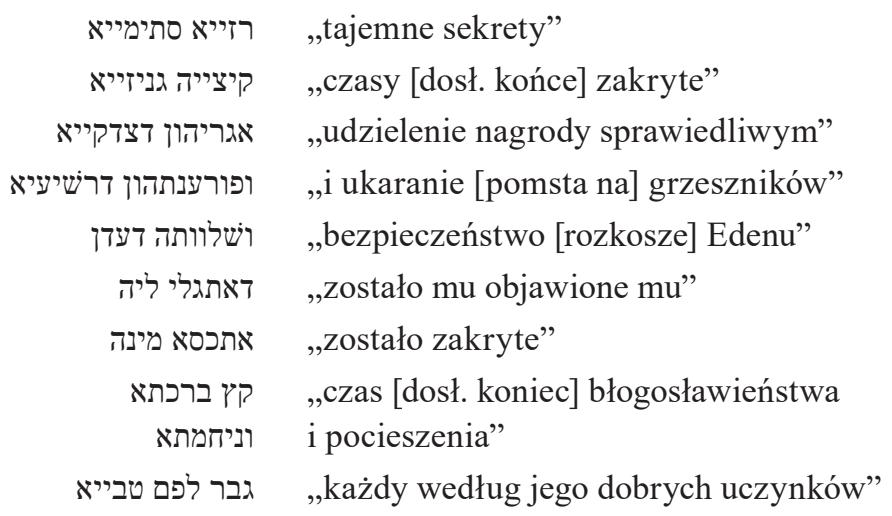

Terminy te obejmują szeroki w zakresie poglądów, od ogólnych wierzeń w nagrodę dla sprawiedliwych, jak i karę dla złoczyńców po śmierci (por. np. $\operatorname{TgN} \operatorname{Rdz} 4,8$ ), jak również w odniesieniu do każdego człowieka i jego czynów. R. Syrén zwraca uwagę, że język użyty w targumach wydaje się być pod wpływem Księgi Daniela

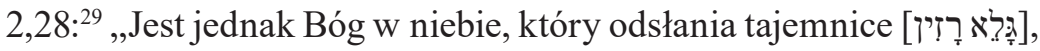
i On oznajmia królowi Nabuchodonozorowi, co nastąpi przy końcu

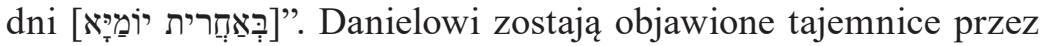
Boga w niebie w sensie apokaliptycznym (por. Dn 2,18.30.47n.). ${ }^{30}$

\footnotetext{
28 Por. TgNmg i TgPsJ Kpł 9,6.

29 R. S y ré n, The Blessings in the Targums, s. 121.

30 Por. też $2 \mathrm{Ba} 81,4$, gdzie są użyte podobne wyrażenia.
} 
Paralele do tego tekstu można odnaleźć także w innych targumach (np. Tg Iz 24,16 ${ }^{31}$ ).

W odróżnieniu od tekstów apokaliptycznych targumy do Rdz 49,1-2 przekazują tekst w trzeciej osobie, a nie w pierwszej, jak to jest zazwyczaj w literaturze apokaliptycznej. Być może targumiści starali się w ten sposób włączyć jak najwięcej z wierzeń i koncepcji, które były akceptowane w ówczesnej tradycji żydowskiej na temat wydarzeń dni ostatecznych. ${ }^{32}$ Targumiści nie tylko starali się uzupełnić braki tekstu biblijnego, ale także objaśnić, dlaczego następujące potem słowa nie objawiają tego, o czym mówi Jakub na wstępie.

Tłumaczenie $\mathrm{TgPs} J$ różni się od $\mathrm{TgN}$ oraz $\mathrm{TgF}-\mathrm{P}$ (por. $\mathrm{TgF} \mathrm{V}$ ) nie tylko wzmianką o oczyszczeniu od nieczystości, lecz mniejszą liczbą terminów ukazujących obraz końca czasów. Podstawowa różnica dotyczy tego, że TgN nie łączy w tym wersecie „końca dni” z przyjściem Mesjasza, jak to czyni TgPsJ i TgF P. W TgN odpowiada mu wzmianka o „końcu błogosławieństwa i pocieszenia”. Informacje o przyjściu Mesjasza w w. 49,1 w TgPsJ poprzedza fraza: „i objawiła się Chwała Szechina JHWH [ דאיתגלי איקר שכינתא דייי]". Użycie czasownika „objawiło się”, „zostało objawione” jest specyficzną cechą techniki translacyjnej, kiedy jest mowa o boskim objawieniu w świecie. ${ }^{33}$ Termin ten poprzedza charakterystyczne zwroty, które są używane w targumach w odniesieniu do JHWH, to jest Jekara $\left(\right.$ (Chwała”) ${ }^{34}$ i Szechina („Obecność”). ${ }^{35}$ Występują one tutaj wraz

31 „Prorok rzekł: «Tajemnica nagrody dla sprawiedliwych stała się jawna mi, została mi objawiona tajemnica odpłaty dla grzeszników»”.

32 R. S y r é n, The Blessings in the Targums, s. 121.

33 W targumach aż dziewięć różnych rdzeni hebrajskich jest oddanych przy użyciu aramejskiego czasownika איתגלי; są to: „zstąpić”, ,zdarzyć się”, przyjść”, „być widzianym”, „pojawić się”, „wiedzieć”, „wstać”, „wyjść” i „przejść”.

34 W Biblii Hebrajskiej jest mowa o tym, że Izraelici widzą „Chwałę” Pańską, która unosi się nad górą Synaj oraz przechodzi przed Mojżeszem. W targumach używane w odniesieniu do tych fragmentów biblijnych, które mogły stać w sprzeczności z koncepcją, zgodnie z którą: „Nikt nie może Mnie oglądać i pozostać przy życiu” (Lb 33,20).

35 Przegląd poglądów na temat tych terminów zob. A. C h e s t e r, Divine Revelation and Divine Titles in the Pentateuchal Targumim, Texte und Studien zum Antiken Judentums 14, J. B. Mohr, Tubingen 1986, s. 312. 
ze skróconym zapisem imienia Pańskiego. ${ }^{36} \mathrm{~W}$ tych fragmentach, w których Biblia mówi o Bożej Obecności, targumy zazwyczaj posługują się wyrażeniem zastępczym szechinta. W kontekście objawienia końca czasów ${ }^{37}$ i przyjścia Mesjasza, Chwała Obecności JHWH w świecie może praktycznie odnosić się do obecności JHWH w świątyni. ${ }^{38}$ Motyw świątyni powraca następnie w TgPsJ do 49,27. Tego rodzaju interpretacja jest zgodna z poglądami rabinicznymi, wywodzącymi się z kręgów faryzejskich. W TgPsJ najodpowiedniejszym miejscem dla Szechiny jest terytorium Benjamina, w granicach którego było miejsce, gdzie można składać ofiary (PsJ Rdz 49,27). ${ }^{39}$ Przyjmuje się, że choć w czasach tłumacza TgPsJ nie istniało już ani królestwo, ani świątynia, to jednak targumista często odwoływał się do tych najważniejszych elementów judaizmu. ${ }^{40}$

W tym kontekście TgPsJ podkreśla, że został zakryty przed nim (Jakubem) konkretny moment w przyszłości, kiedy przyjdzie Mesjasz, król (מלכא משיחא). ${ }^{41}$

36 Por. objawienie dane Balaamowi a zakryte przed prorokami (targumy do Lb 24,17-20), nagroda przygotowana dla Izraela w przyszłym świecie (Tg Lb 23,23), Boża odpłata na niegodziwcach (Tg Lb 24,23).

37 Wj 16,7.10; 24,16; 33,18.22. „Chwała” ewidentnie zastępuje samego Boga, ponieważ w bezpośrednim kontekście występuje słownictwo paralelne: „Ponieważ człowiek nie może M n i e zobaczyć” (w. 20) czy: „Położę rękę, aż J a przejdę” (w. 22).

38 Zob. np. „Kiedy przybędą tu w czasie utrapienia (...) przebacz im grzechy (...) tak, żeby przyszłe pokolenia mogły mówić: Na wzgórzu świątyni Pańskiej Abraham składał w ofierze swego syna Izaaka. Również na tej górze, która jednocześnie jest miejscem sanktuarium, ukazała mu się Chwała Obecności Pańskiej” (PsJ Rdz 22,14).

39 A. K u ś m i r e k, Świątynia jerozolimska w targumach, Colleectanea Theologica 79 (2009) nr 2, s. 65-76.

40 B. P. M o r t e n s e n, The Priesthood in Targum Pseudo-Jonathan: Renewing the Profession, Studies in Aramaic Interpretation of Scripture 4, Brill Academic Publishers 2006, s. 173.

${ }_{41}$ M. S h e p h a r d, Targums, The New Testament, and Biblical Theology, JETS 51(2008) nr 1, s. 53. 
Choć temat Mesjasza występują dość rzadko w targumach, ${ }^{42}$ to jednak w błogosławieństwie Jakuba powraca tym razem we wszystkich przekładach jeszcze w Rdz 49,10-12.

Choć werset $2 \mathrm{w}$ TgO i TgPsJ nie zawiera wiele zmian, to jednak warto zwrócić uwagę na użyty tam aramejski zwrot ,a otrzymacie pouczenie [אולפן]", który odpowiada wezwaniu skierowanym do synów Jakuba, aby słuchali tego, co powie im ojciec. Za pierwszym razem czasownik „słuchajcie” został użyty przez targumistę, natomiast w drugim przypadku wydaje się, że rozumiał, iż odnosi się on do czegoś bardziej konkretnego niż jedynie „słuchanie”, mianowicie pouczenie, które otrzymują synowie Jakuba.

$\mathrm{TgN}$, podobnie jak manuskrypty TgF, powtarzają zakończenie w. 1, ponadto dodają dodatkowy materiał haggadyczny, w którym błogosławieństwo Jakuba rozpoczyna się badaniem wierności plemion Izraela wobec Boga JHWH. Jakub nawiązuje tu do synów Abrahama i Izaaka, czyli do Izmaela, a także synów Ketury i Ezawa, którzy oddawali cześć obcym bóstwom. W odpowiedzi plemiona/synowie Jakuba recytują wyznanie wiary Izraela w jedynego Boga, Szma ${ }^{43}$ w wersji aramejskiej: שמע מנן ישראל אבונן ייי אלהן ייי חד (Stuchaj Izraelu, nasz ojcze! PAN (JHWH), nasz Bóg, PAN (JHWH) jest jeden". W TgN Jakub odpowiada słowami:

Niech Jego imię będzie błogosławione i niechaj chwała Jego ${ }^{44}$ królestwa trwa na wieki wieków". Formuła ta była odpowiednikiem wyznania wiary w czasach późniejszych w judaizmie rabinicznym. ${ }^{45}$ Wypowiedzi tej brakuje TgF (P, VNL).

Paralele do interpretacji targumów znajdują się w literaturze rabinicznej, np. w Talmudzie Babilońskim (Pes. 56a):

42 Zob. targumy do Rdz 3,15; Lb 11,26; Lb 24,7.17; Wj 12,42.

43 Zob. ten sam midrasz w TgN Pwt 6,4.

${ }^{44} \mathrm{~W}$ tekście użyto hebrajskiego słowa $\mathrm{W}$ TgN zostało dodano hebrajskie słowo , chwała” z aram. sufiksem 3 os. m. 1. poj. Uważa się, że dodanie tego słowa jest prawdopodobnie interpolacją do TgN. K. C a t h c a r t, M. M a h e r, M. M c N a m a r a (red.), Targum Neofiti 1: Genesis, przyp. do 49,2.

45 B. Gro s s fe 1 d, Targum Neofiti, przyp. 2 do Rdz 49. 
„Jakub zapragnął ukazać swoim synom «koniec dni», ale w tym momencie opuściła go Szechina. Rzekł więc: «Niebiosa mi tego zakazały, może jednak któryś z moich synów nie jest tego godzien: z Abrahama wyszedł Izmael, a z Izaaka - Ezaw». Odpowiedzieli mu synowie: «Słuchaj, Izraelu, Pan nasz Bóg jest Panem jedynym». Jakub natychmiast zawołał: «Błogosławione niech będzie imię Jego chwalebnego królestwa teraz i na wieki»".

Odpowiedź synów Jakuba powstała w nawiązaniu do imienia Izrael, nadanego Jakubowi, które zostało użyte w Pwt 6,4.

W tym kontekście warto przytoczyć także midrasz Genesis Rabba, który zawiera komentarz do tego fragmentu:

„Eleazar ben Ahwai rzekł: «Na tej podstawie Izrael zyskał prawo do recytowania Szma». Kiedy Jakub nasz ojciec miał już pożegnać się ze światem, przywołał swych dwunastu synów i rzekł: «Czy Bóg Izraela, który zasiada w niebiosach, jest waszym ojcem? Czy w waszych sercach nie kryje się chęć odstąpienia od Świętego, niech będzie błogosławiony?» Ci odpowiedzieli: «Słuchaj, Izraelu, nasz ojcze: podobnie jak w twoim sercu nie kryje się chęć odstąpienia od Niego, tak też i my nie mamy takiego zamiaru; przeciwnie, Pan nasz Bóg jest Panem jedynym». A on zawołał: «Błogosławione niech będzie imię Jego chwalebnego królestwa teraz i na wieki». Rabbi Berekiasz i rabbi Helbo rzekli w imieniu rabbiego Samuela: «Oto dlaczego rano i wieczorem Izrael powtarza: Słuchaj, Izraelu, nasz ojcze, z groty Makpela: to co nam przykazałeś, nadal wypełniamy; Pan nasz Bóg jest Panem jedynym»” $(98,3)$. 


\section{Obraz Mesjasza w błogosławieństwie Judy w targumach $(49,8-12)$}

Jedno z oczekiwań cieszących się dużym powodzeniem dotyczyło przyjścia Mesjasza w charakterze króla, który będzie pochodzić z dynastii Dawidowej, zapewni Izraelowi zwycięstwo nad narodami pogańskimi i zaprowadzi czasy pokoju i sprawiedliwości. Mimo to o Mesjaszu względnie o Królu-Mesjaszu, tak jak jest zwany w Targumach Palestyńskich, spotykamy w targumach stosunkowo mało wzmianek. $^{46}$

Powraca on w kontekście słów skierowanych do plemienia dla Judy (49,8-12). Podobnie jak w przypadku innych plemion autor tekstu hebrajskiego posługuje się metaforą, charakteryzując kolejne plemiona za pomocą symboli zwierząt, takich jak lew, osioł, wąż czy też wilk. W 49,8-9 podkreślają wielkości i potęgę szczepu Judy, który kiedyś był podobny do młodego lwa, z biegiem czasu stał się jak stary lew, który po łowach odpoczywa sobie spokojnie, bo jego siła budzi powszechny strach i stąd nikt nie ośmieli się mu przeszkadzać: ${ }^{47}$

${ }^{8} \mathrm{Judo}$, ciebie sławić będą twoi bracia, twoja bowiem ręka na karku twych wrogów!

Synowie twego ojca będą Ci oddawać pokłon!

${ }^{9}$ Judo, młody lwie, na zdobyczy róść będziesz, mój synu:

Jak lew się czai, gotuje do skoku

Do lwicy podobny - któż się ośmieli go drażnić?"

Fragment ten w głównych targumach został przetłumaczony w ten sposób:

46 M. P. F e r $\mathrm{n}$ a n d e z, Tradiciones mesianicas en el Targum Palestinense. Estudios exegeticos, Valencia-Jerusalen 1981.

47 Por. Lb 23, 24; 24, 9. 


\section{TgO}

${ }^{8}$ Judo, jesteś moją chlubą, a nie okryłeś się niesławą. Twoi bracia uznają twą wyższość. Ręka twa silna będzie przeciw twym wrogom, twoi wrogowie zostaną rozproszeni. Ich karki ugną się przed tobą, synowie twego ojca zawsze spieszyć się będą, by przekazać ci pozdrowienie, wyprzedzając przywitanie $\mathrm{z}$ twojej strony.

${ }^{9}$ Władcą będzie na początku, zaś na końcu $\mathrm{z}$ domu Judy powstanie król pełen mocy, ponieważ to dzięki tobie, mój synu, dusza twoja uratowała się z wyroku śmierci. Będzie żył w spokoju, spoczywać będzie niewzruszony jak lew, jak silny lew, a nie ma królestwa, które będzie go niepokoić.

\section{$\operatorname{TgN}$}

${ }^{8}$ Judo, ciebie sławić będą bracia twoi i z powodu twojego imienia wszyscy Żydzi będą nazywani Żydami. Twoje ręce pomszczą twoich wrogów. Wszyscy synowie twego ojca przybliżą się, aby oddawać ci pokłon!

${ }^{9}$ Porównam cię, Judo, do
młodego lwa. Ocaliłeś
mego syna Józefa przed
jego zabójcami. Od sądu
Tamar, mój synu, jesteś
uniewinniony. Będziesz
spoczywał i mieszkał
w środku bitwy, jak lew
i lwica. A nie będzie
narodu i królestwa, które
przeciwstawi się tobie.

${ }^{9}$ Porównam cię, Judo, do młodego lwa. Ocaliłeś mego syna Józefa przed jego zabójcami. Od sądu Tamar, mój synu, jesteś uniewinniony. Będziesz spoczywał i mieszka w srodku bitwy, jak lew i lwica. A nie będzie przeciwstawi się tobie.

\section{TgPsJ}

${ }^{8}$ Judo, przyznałeś się w związku z incydentem z Tamar, dlatego twoi bracia będą cię wychwalać i wedle twego imienia będą nazywani Żydami. Twoje ręce dokonają pomsty na twych wrogach, ciskając na nich strzały, gdy odwrócą się plecami do ciebie. A synowie twego ojca będą ci wychodzić naprzeciw na powitanie.

\footnotetext{
${ }^{9}$ Porównuję cię, Judo, mój synu, do szczenięcia, młodego lwa, bo twoja dusza trzymała się z dala od zabójstwa mego syna Józefa i od sądu [nad] Tamar, którą ocaliłeś. Spoczywasz w sile i jesteś spokojny, jak lew i jak lwica - kiedy odpoczywa, kto go zbudzi?
}

W przekładach aramejskich poetyckie metafory z tekstu hebrajskiego rzadko są zachowane jako takie. Targumiści pomijają je zupełnie lub zmieniają na zrozumiałe, często stosując bardziej opisowy język. W ten sposób zastępują właściwe tłumaczenie wyjaśnieniem tekstu specyficznym dla danego targumu.

W przekładach tych można odnaleźć także jeszcze inną technikę translacyjną, którą stosują meturgemani, odwołując się do różnych znaczeń słów. Przykładem tutaj jest podwójne tłumaczenie hebrajskiego terminu יוּ' Targumy interpretują zgodnie z podwójnym znaczeniem tego słowa: „sławić/wychwalać” oraz „,przyznać się". Przyznanie się, o którym TgN i TgPsJ mówią wprost, a TgO 
pośrednio, związane z historią Tamar, zostało opisane w Rdz 38,26 (por. GenR 99,8).

Słowo „lew” w tym wierszu $\mathrm{TgO}$ odczytuje jako symbol króla, a potem wprowadza tu wątek mesjanistyczny. Natomiast TgN i TgPsJ interpretują to inaczej.

Następnie w tekście masoreckim Rdz 49,10-12 zostaje ukazany metaforyczny opis Judy:

\author{
${ }^{10} \mathrm{Nie}$ będzie odjęte berło od Judy, \\ ani dający prawo od nóg jego, aż przyjdzie Sziloh, ${ }^{48}$ \\ i on zdobędzie posłuszeństwo narodów. \\ "Przywiąże w winnicy swego osiołka, \\ a źrebię ośle u winnych latorośli. \\ W winie prać będzie swą odzież, \\ i w krwi winogron - swoją szatę. \\ ${ }^{12}$ Będą mu się iskrzyły oczy od wina \\ A zęby będą białe od mleka".
}

Przekład targumów:

\begin{tabular}{llll} 
TgO & Tg N & Tg F P & Tg PsJ \\
\hline${ }^{10}$ Nie ustanie pa- & ${ }^{10}$ Nie ustaną & ${ }^{10}$ Z domu Judy nie & ${ }^{10}$ Spośród tych z domu \\
nowanie w domu & [powstawać] & przestaną [po- & Judy nie przestaną \\
Judy, ani pisarza & królowie spośród & chodzić] królowie & [pochodzić] królowie \\
spośród dzieci & tych z domu Judy & i władcy, ani pisarze & i władcy oraz uczeni \\
jego dzieci na & ani pisarze uczący & nauczający Prawa & nauczający Prawa \\
wieki, póki nie & Prawa od synów & spośród potomstwa & z jego potomków, aż \\
przyjdzie Me- & jego synów, aż do & jego dzieci, aż do & do czasu, [gdy] przyj- \\
sjasz, do którego & czasu przyjścia & czasu, kiedy przyj- & dzie Król Mesjasz, \\
należy królestwo, & Króla Mesja- & dzie Król Mesjasz, & najmłodszy z jego \\
a narody będą mu & sza, do którego & do którego należy & synów, z powodu któ- \\
posłuszne. ${ }^{\text {a }}$ & należy panowanie & królestwo, a wszyst- & rego ludzie umierać \\
& i któremu będą & kie królestwa ziemi & będą z rozpaczy. \\
& podlegać wszyst- & będą Mu służyły. & \\
& kie królestwa. & &
\end{tabular}

48 Możliwe thumaczenie: ,aż przyjdzie ten, do którego ono należy”. 


\section{TgO}

${ }^{11}$ Izrael zadba

o swoje miasta, lud zbuduje świątynię, sprawiedliwy zadba o siebie i będzie wiernie przestrzegał Prawa. Jego odzienie z najczystszej purpury, jego ubranie z wełny soczyście i kolorowo barwione.

\begin{abstract}
${ }^{12}$ Jego góry będą czerwone od winnic, a tłocznie ociekać będą winem. Jego doliny bielić się będą zbożem i stadami owiec.
\end{abstract}

Tg N

${ }^{11}$ Jak szlachetny

jest król Mesjasz, który powstanie z domu Judy! Przepasał swe biodra i wyruszył do walki ze swymi wrogami, i zabijał królów i ich namiestników. Góry pokrył czerwienią krwi ich członków, a wzgórza bielą tłuszczu możnowładców. Odzienie jego skąpane we krwi.

${ }^{12}$ Jak piękne są oczy Króla Mesjasza, bardziej niż wino, aby nimi nie dostrzegać nagości i ani rozlewu krwi niewinnych. Jego zęby są bielsze niż mleko, aby nimi jeść [rzeczy] ukradzionych i pełnych przemocy. Pagórki staną się czerwone od jego wina i kadzi winnych, a wzgórza staną się białe od obfitości zboża i stad owiec".

\section{Tg F P}

${ }^{11}$ Jak szlachetny jest król Mesjasz, który powstanie $z$ domu Judy! Przepasał swe biodra i wyruszył do walki ze swymi wrogami, i zabijał królów i ich namiestników. Góry pokrył czerwienią krwi ich członków, a wzgórza bielą tłuszczu możnowładców. Odzienie jego skąpane we krwi.
Tg PsJ

${ }^{11}$ Jak piękny jest Król Mesjasz, który ma powstać spośród tych z domu Judy! Przepasuje swe biodra i przybywa ustawiając szyki bojowe przeciw swym wrogom i zabijając królów razem $\mathrm{z}$ ich władcami, a nie ma króla ani władcy, który mógłby mu się przeciwstawić. Sprawia, że góry stają się czerwone od krwi zabitych, jego szaty spływają krwią, jest jak ten, który wyciska grona.

\section{${ }^{12}$ Oczy Króla}

Mesjasza szlachetniejsze niż wino musujące: nie będą oglądać odsłonięcia nagości ani rozlewu niewinnej krwi.

Zębami posługuje się zgodnie z Prawem i nie spożywa tego co ukradzione czy rozszarpane. Jego góry czerwone od winnic, a jego prasy od wina; jego wzgórza białe od zboża i od stad owiec.
${ }^{12}$ Jak piękne ${ }^{34}$ są
oczy Króla Mesjasza! [Są] jak czyste wino, bo nie oglądały ${ }^{35}$ odkrytej nagości ani przelewania niewinnej krwi. Jego zęby bielsze od mleka, bo nie jadł niczego, co było ukradzione lub zabrane siłą. Jego góry i jego tłocznia będą czerwone od wina, a jego wzgórza bieleją zboża i stadami.

a Lub „będą mu służyły”. 
Już na początku w. 10 przekłady aramejskie przekazują parafrazę tekstu hebrajskiego, rzeczownik שבט (,berło") interpretują jako przyszłych władców z plemienia Judy. Natomiast hebrajski termin מחקק (,laska pasterska” - BT) może odnosić się do ,służby” czy też „personelu władcy”. Targumy jednak wywodzą od od (,prawo”, „dekret”), a wyrażenie „spośród jego stóp/nóg” interpretują w odniesieniu do przyszłych potomków. Na podstawie tego w targumach jest mowa o ,pisarzach”, „uczonych” (TgO: סָפְרָא czy też ,pisarzach, nauczających Prawa" (Tg PsJ: וספרין מאלפי אורייתא por. TgN; TgF); TgO: „oraz pisarz spośród dzieci jego dzieci”. ${ }^{49}$

W ten sposób do tekstu biblijnego zostaje wprowadzona aktualizacja związana z późniejszą instytucją. W wersecie tym pojawia się także charakterystyczne uzupełnienie dla targumów, mianowicie mówi się nie o samym patriarsze, lecz o „domu Judy”.

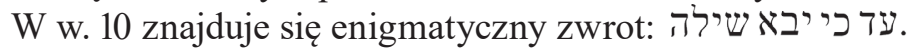

Jeśli שילה to nazwa własna, zatem powstaje sens: „póki nie przyjdzie Szilo". Jeśli jednak jest to partykuła względna (ש) połączona z przyimkiem i zaimkiem 3. osoby męskiej iל, zwrot można rozumieć jako: „póki nie przyjdzie ten, do którego [to] należy”. Hebrajski tekst Rdz 49,10 targumy interpretują zgodnie z zasadami gematrii czy odpowiednika liczbowego. Hebrajskie słowo Mesjasz - שיח ma dokładnie taką samą wartość liczbową $(358)^{50}$ jak litery wyrażenia: „przyjdzie šilōh [שילה יבא]". Zgodnie z gematrią to dziwne wyrażenie kryje w sobie sens: „póki nie przyjdzie Mesjasz”. W targumach nie ma takiej dwuznaczności. Taką interpretację podają przekłady aramejskie, a także inne starożytne świadectwa. ${ }^{51} \mathrm{O}$ ile w TgO jest mowa o przyjściu Mesjasza, do którego należy królestwo, to w pozostałych targumach określany jest jako Król Mesjasz (מלכא משיחא).

\footnotetext{
49 Por. GenR 97; b. Sanh. 5a.

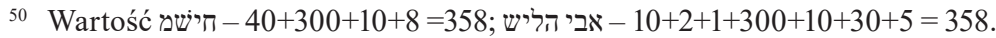

${ }_{51}$ Taka sama mesjańska interpretacja Rdz 49,10 występuje w Qumran (4QM 3-4) i w Dokumencie Damasceńskim.
} 
W TgPsJ występuje w tym miejscu jeszcze jedno doprecyzowanie: „najmłodszy [ זעיר] z jego synów”, które może wynikać z faktu, że autor połączył - „Szilo” z imieniem „Szela”, z najmłodszym synem Judy (por. Rdz 38,5) lub też ze zwrotem: „łożysko [od שִלְיָּ] które wyszło spomiędzy jej nóg" w Pwt 28,57, który TgO tłumaczy jako: „najmłodsze [ זעיר-tego słowa używa też TgPsJ w tym wierszu] z dzieci, które ona wydaje na świat".

W tekście hebrajskim ww. 11-12 opisują pomyślne warunki, w jakich znajduje się szczep Judy. Poeta biblijny ukazuje czytelnikowi nowe szczegóły bezpieczeństwa i pokoju, podkreślając dobrobyt kraju. Wyraża to również wizja krzewów winnych, które się tak rozrosły się, że mieszkańcy tej ziemi przywiązują do nich swe osły, nie martwiąc się tym, że zwierzęta zniszczą ich cenne uprawy. Wina jest tak dużo, że członkowie szczepu piorą w nim swoje ubrania i obficie piją ten napój, czego dowodem są ich mętne oczy. Na ich zębach zaś widać ślady mleka, którego również jest pod dostatkiem.

Przekład targumów, szczególnie w. $11 \mathrm{w}$ niewielkim stopniu przypomina tekst biblijny. Hebrajski czasownik („wiązać”), który w tekście hebrajskim występuje w sensie ,przywiązywać”, „pętać” (np. osła) tłumacze pojmowali zupełnie inaczej, mianowicie jako „przypasać (miecz)”, co z kolei prowadzi do przedstawiania Mesjasza jako wojownika.

$\operatorname{TgN}$ i TgF i TgPsJ zawierają podwójny opis Mesjasza, o ile w. 11 przedstawia obraz wojownika i zdobywcy, to w w. 12 jest on ukazany jako orędownik pokoju. W opisie tym wykorzystano niektóre z elementów metafory tekstu hebrajskiego.

Obie koncepcje mogły należeć do tego samego dokumentu, uzupełniając się nawzajem. Podwójny opis Mesjasza w Targumach Palestyńskich Rdz 49,11-12 (TgN, TgF, także TgPsJ) uznaje się za jeden poemat mesjanistyczny, który obejmuje aspekt wojenny tej postaci (w. 11), jak i pokojowy (w. 12). Ich paralelizm antytetyczny 
i identyczne słownictwo wskazują, że tworzyły one spójny utwór i wyszły spod ręki jednego autora. ${ }^{52}$

Natomiast Targum Onkelosa w miejsce opisu działania Mesjasza w w. 11 mówi, o Izraelu, który ma zadbać o miasta, a naród zbuduje Świątynię ( היכְליה:). Jest on przedstawiany dalej jako sprawiedliwy, który będzie wiernie przestrzegać Prawa. Targum Onkelosa dąży do zrewidowania obrazu tego, który ma przyjść, zastępując Mesjasza wojownika wizerunkiem Mesjasza jako nauczyciela Tory. Zmiana wprowadzona przez Onkelosa mogła wynikać z innej sytuacji politycznej, jaka nastała po nieudanym powstaniu żydowskim przeciw Rzymianom. $^{53}$

\section{Interpretacja błogosławieństw w targumach na przykładzie Issachara i Benjamina}

W tekście hebrajskim wypowiedzi Jakuba skierowane do poszczególnych plemion to ukazanie ludzkich charakterów i zachowań, jak również boskich zamierzeń związanych z tymi szczepami. W wielu z nich autor biblijny wykorzystuje metafory zwierząt, które $\mathrm{w}$ targumach zyskują odmienną interpretację. Zmiany takie zostaną omówione na przykładzie Issachara $(49,14-15)$ i Beniamina $(49,27)$.

52 M. P. Fe r n a n d e z, Tradiciones mesianicas en el Targum Palestinense. Estudios exegeticos, s. 141n.

${ }_{53}$ Tamże, s. 143. Taka sama koncepcja mesjańskiego króla wojownika i wyzwoliciela pojawia się w TgF Lb 24,7 w interpretacji proroctwa Balaama: „Spośród ich synów powstanie ich król, spośród nich wyjdzie ich wyzwoliciel. Uprowadzonych w niewolę ponownie zgromadzi z krajów ich nieprzyjaciół, a ich synowie rządzić będą nad wieloma narodami. On mocniejszy będzie od Saula, który ulitował się nad Agagiem, królem Amalekitów, a panowanie Mesjasza-Króla zostanie wywyższone”. Biblijne ,berło” i „gwiazdę” Jakuba Tg Lb 24,17 interpretuje w sensie mesjanistycznym, podobnie Qumran i Nowy Testament (4QTest: CD 7,18-21; Mt 2,1nn.; Łk 1,78n.). W targumie czytamy: „Powstanie król z domu Jakuba, wyzwoliciel i władca z domu Izraela. On zgładzi królów Moabu i wyniszczy wszystkich synów Seta”. 


\section{Issachar}

Tekst hebrajski 49,14-15:

${ }^{14}$ Issachar — osioł kościsty, Wylegujący się między zagrodami"

${ }^{15}$ Gdy spostrzegł, że ma dobre leże, że [jego] ziemia — przyjemna, pochylił plecy do dźwigania brzemion, stał się najemnym sługą" (tłum. BPz). ${ }^{54}$

\section{TgO \\ ${ }^{14}$ Issachar, zasobny w bogactwa, jego dziedzictwo między granicami”.}

${ }^{15}$ I ujrzał swój dział, że jest dobry, oraz ziemię, że rodzi owoce; i podporządkuje sobie tereny narodów i rozproszy ich mieszkańców, ci zaś, którzy pozostaną, będą mu służyć i składać daninę.

\section{$\operatorname{TgN}$}

${ }^{14}$ Issachar plemię mocne leżące między dwoma obszarami.

${ }^{15}$ Zobaczył od
początku, że [jego
powierzchnia]
była dobra i że
ziemia Izraela
dawała obfite
owoce. I skłonił
swoje ramiona
do studiowania
Prawa, a wszyscy
jego bracia płacili
mu trybut.

${ }^{15}$ Zobaczył od

${ }^{15}$ Zobaczył dom świątyni zwany Domem Odpoczynku, że jest dobry i ziemia [P: Izraela] owocująca i thusta, schylił swe ramiona do pracy w Prawie, a wszyscy jego bracia składać mu będą daninę.

\section{TgPsJ}

${ }^{14}$ Issachar obciążony jest Prawem. Jest silnym pokoleniem, znającym uwarunkowania czasów, a [jego dział] rozmieszczony jest na terytoriach jego braci.

${ }^{15}$ Widział, że spoczynek przyszłego świata jest dobry i że jego dział [na] ziemi Izraela jest przyjemny, dlatego ugiął swe ręce do pracy według Prawa, a jego bracia składali mu dary.

54 Por. „Issachar - osioł kościsty, będzie się wylegiwał ufny w swe bezpieczeństwo. Widzi on, że dobry jest spoczynek, a kraj uroczy; ale będzie musiał ugiąć swój grzbiet pod brzemieniem i stanie się niewolnikiem, pędzonym do pracy" (BT). 


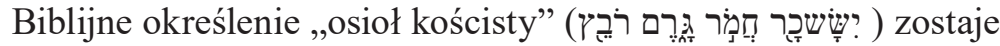
zmienione w targumach. W TgO odnosi się ono do posiadłości, plemienia Izraela (1Krn 12,32). Być może targumiści uznali, że porównanie tego szczepu do osła jest nie do przyjęcia. $Z$ tego powodu podają alternatywne tłumaczenie, jakim jest pochwała Issachara i odniesienia do obszaru, gdzie mieszkał (TgPsJ). Innym sposobem interpretacji tego określenia jest zaakcentowanie mocy plemienia, którego symbolem mógł być „silny kościsty osioł” (TgN). Podaje on także jeszcze jedną interpretację, wskazując na bogactwo tego plemienia w nawiązaniu do w. $15 .{ }^{55}$

TgPsJ jako jedyny już w w. 14 zwraca uwagę na znajomość Prawa przez Issachara. Tłumacz $w$ tym targumie inaczej interpretuje słowo חִמר (,osioł") z tekstu masoreckiego, według niego chodzi tu o termin חמיד (,,tęsknota”), ${ }^{56}$ która jest skierowana właśnie w kierunku Prawa. ${ }^{57}$ TgPsJ dodaje także informację o „wyznaczonym czasie” (por. TgPsJ 46,13), która może wynikać z opinii, jaką miało to plemię: „Z synów Issachara, odznaczających się głębokim zrozumieniem czasów i znajomością tego, co ma czynić Izrael, dwustu dowódców, oprócz wszystkich ich braci pod ich dowództwem" (1Krn 12,33).

Tłumaczenie w targumach hebrajskiego terminu szar”, „granice” może wynikać z hebrajskiego rdzenia $s-p-h$, które ma znaczenie „brzeg”, „skraj”, „granica”.

Przekład w. 15 jeszcze raz akcentuje gorliwość studiowania Prawa przez Issachara. Biblijny poeta ukazuje sielankowy obraz miejsca, nie tylko do spoczynku, lecz także jako dobre do zamieszkania ze względu na płodną ziemię, ${ }^{58} \mathrm{o}$ czym wyraźnie mówią przekłady TgPal

55 Por. Talmud Babiloński (B. Qama 17a).

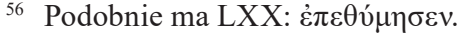

57 W midraszu Genesis Rabba $(98,12$ i 99,10) jest mowa o tym, że ,jak osioł niesie ładunek, tak Issachar jest obciążony jarzmem Tory”. Podobnie Tanhuma i Raszi podają taką samą interpretację na innej podstawie: „Dźwiga Torę jak silny osioł, na którego złożono ciężki ładunek".

58 Według podziału był to obszar położony na wschodnim krańcu żyznej dolinie Jezreel (Joz 19,17-22) umieszczonej między działem Zabulona i rzeką Jordan. 
i TgPsJ. Jednak ten ostatni jako jedyny wprowadza do tego wiersza ideę ,przyszłego świata”.

Obraz przedstawiony w Rdz 49,14 ukazuje silne plemię, które na dobrej ziemi podejmuje ciężką pracę (w. 15). W tekście hebrajskim w. 15 wyraża to fraza: ,zgiął plecy, aby dźwigać”, a dalej jest mowa, że stało się „ludem zmuszanym do pracy”. Targumy zmieniają przesłanie tekstu hebrajskiego. Dla tłumaczy nie do przyjęcia jest pogląd, że błogosławione plemię Izraela, mogłoby zgodzić się na zniewolenie. W konsekwencji tłumacze interpretują ten tekst w odmienny sposób. TgO hebrajskie sformułowanie ,pochylenie ramion/barków”

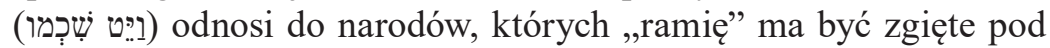
jarzmem Issachara. Może zatem chodzić, podobnie jak 49,13 o zapowiedź podbojów terytorialnych, a w konsekwencji do składania prze nich danin. ${ }^{59}$

Natomiast w TgPal i TgPsJ, a także w większości midraszy Issachar ,pochyla ramiona”, aby studiować Torę, a daniny składają mu jego bracia.

\section{Beniamin}

Przekład tekstu masoreckiego 49,27:
„Beniamin - wilk drapieżny, co rano rozrywa zdobycz, a wieczorem rozdziela łupy".

59 Alternatywnie שְִׁכמש można przełożyć, podobnie jak שכם Rdz 48,22, gdzie TgO tłumaczy jako „część”. W tym przypadku tłumaczenie może brzmieć: ,, pochylił ich część" (terytorium innych narodów); zob. B. Gros s fe 1, M. A b e rb a c h, Targum Onkelos to Genesis, s. 294n. 


\begin{tabular}{|c|c|c|c|}
\hline TgO & $\operatorname{TgN}$ & $\operatorname{TgF} P, V, N$ & TgPsJ \\
\hline $\begin{array}{l}\text { Benjamin, na jego } \\
\text { ziemi zamieszka } \\
\text { Szechina, w jego } \\
\text { posiadłościach } \\
\text { zbudowana zo- } \\
\text { stanie świątynia. } \\
\text { Rano i wieczorem } \\
\text { kapłani składać } \\
\text { będą ofiary, } \\
\text { a w południe } \\
\text { rozdzielą to, co } \\
\text { pozostało jako } \\
\text { ich dział, resztki } \\
\text { świętych rzeczy }\end{array}$ & $\begin{array}{l}\text { Beniamin to ple- } \\
\text { mię potężne. }{ }^{a} \text { Na } \\
\text { jego obszarze po- } \\
\text { wstanie świątynia } \\
\text { i w jego dziedzi- } \\
\text { ctwie zamieszka } \\
\text { Chwała Obecności } \\
\text { Pana. Z rana ka- } \\
\text { płani będą składać } \\
\text { nieustającą ofiarę } \\
\text { z baranka, a wie- } \\
\text { czorem podzielą } \\
\text { się tym, co zostało } \\
\text { z ofiar synów } \\
\text { Izraela. }\end{array}$ & $\begin{array}{l}\text { Benjamin to plemię } \\
\text { silne podobne do } \\
\text { gwałtownego nie- } \\
\text { dźwiedzia. W jego } \\
\text { granicach zbudowana } \\
\text { zostanie świątynia, } \\
\text { w jego posiadłościach } \\
\text { zamieszka Chwała } \\
\text { Szechina Pana. Ran- } \\
\text { kiem składać będą } \\
\text { w ofierze zwykłą } \\
\text { owcę, w południe } \\
\text { owcę tamid, a wie- } \\
\text { czorem złożą owcę } \\
\text { na ofiarę całopalną } \\
\text { i rozdzielą to, co } \\
\text { pozostanie z ofiar } \\
\text { składanych przez } \\
\text { dzieci Izraela. }\end{array}$ & $\begin{array}{l}\text { Beniamin to plemię } \\
\text { potężne, jak wilk } \\
\text { ze swą zdobyczą. } \\
\text { Szechina Pana } \\
\text { świata zamieszka } \\
\text { na jego ziemi, a na } \\
\text { [terenie] jego dzie- } \\
\text { dzictwa zbudowana } \\
\text { zostanie świątynia. } \\
\text { Rano kapłani skła- } \\
\text { dać będą regularną } \\
\text { ofiarę z barana aż do } \\
\text { godziny czwartej, } \\
\text { a o zmierzchu złożą } \\
\text { drugiego barana, } \\
\text { wieczorem zaś to, } \\
\text { co zostało z resztek } \\
\text { ofiar, rozdzielą [tak, } \\
\text { że] każdy spożyje } \\
\text { swoją część". }\end{array}$ \\
\hline
\end{tabular}

a Nfmg: ,podobne do niedźwiedzia gwałtownego i na [jego] terytorium”.

Metafora wilka pozostała w wersji TgF i TgPsJ. Wydaje się, że wilk - drapieżna bestia - nie był zbyt odpowiedni jako metafora plemienia Izraela. Może o tym świadczyć fragment Testamentu Beniamina z w II w. przed Chr.: „I już nie będę nazywany wilkiem drapieżnym z powodu waszej drapieżności, ale robotnikiem Pana rozdzielającym żywność tym, co dobrze pracują" (11). ${ }^{60}$

Natomiast targumiści podjęli się zadania objaśnienia tego wersetu na temat patriarchy, o którym w tradycji żydowskiej mówiono, że

${ }^{60}$ A. P a c i o r e k (tłum.), Testamenty Dwunastu Patriarchów-synów Jakuba, w: R. R u b i n k i e w i c z (oprac. i wstępy), Apokryfy Starego Testamentu, PSB 13, Oficyna Wydawnicza „Vocatio”, Warszawa 1999, s. 81. 
był pozbawiony wszelkiego grzechu, a nawet był tak doskonały, że anioł śmierci nie miał nad nim władzy (por. b.Šabb. 55b; b.Bath. 17a).

Aramejscy tłumacze interpretowali ten werset jako wywyższenie Benjamina, ponieważ to na jego terytorium będzie mieszkać Szechina (TgO, TgPal i TgPsJ). ${ }^{61}$ Wzmianka z tekstu hebrajskiego o porach dnia w targumach nawiązuje do ofiar składanych przez kapłanów w świątyni. Targumiści mieli podstawy, aby sławić Beniamina w związku ze świątynią i sprawowanym w niej kultem. ${ }^{62}$

Tekst hebrajski mówi o dzieleniu resztek z ofiar. Obie ofiary codzienne były zużywane w całości, dlatego tłumacze dodali też inne ofiary, aby wzmiance biblijnej o „dzieleniu” nadać sens. W celu umożliwienia takiego uzupełnienia, dodawano słowo: „wieczorem”, chociaż już wcześniej przetłumaczono je jako „,zmierzch” (TgN, P, TgPsJ), ,zachód” (V, N) lub ,pod wieczór” (TgO).

Werset 28 zamyka błogosławieństwo Jakuba w targumach. Akcentuje się tutaj, że ,wszyscy z nich sprawiedliwi jak jeden”. ${ }^{63} \mathrm{~W}$ ten sposób tłumacze podkreślają, że kiedy Jakub skończył błogosławić poszczególne pokolenia, każdemu z nich przypisując szczególne wartości, przywileje i zapowiadając ich przyszłość, nie skończył jeszcze swej wypowiedzi, lecz pobłogosławił wszystkich jako grupę. W ten sposób żadne z pokoleń nie mogło uważać się za ważniejsze od pozostałych. Pogląd ten opiera się na biblijnym stwierdzeniu: „pobłogosławił ich”.

Przekłady wersji aramejskich Rdz 49,1-8, szczególnie TgPal i TgPsJ, zawierają wiele uzupełnień i objaśnień, wśród których można odczytać późniejsze elementy popularnej wiary. Warto zauważyć, że targumy uzasadniają też dlaczego Jakub nie przekazał objawienia w tekście hebrajskim, ponieważ tajemnica została zakryta przed nim

${ }_{61}$ Zob. też Pwt 33,12; Mechilta de R. Shimon b. Yohai do Wj 14,22; b. Meg. 26a.

62 Por. GenR 99,1; b. Yoma 12a; b. Meg. 26a; b. Zebah. 54a; ARN A 35.

63 Por. GenR 99,4; Tanhuma Wa-Yehi 16. 
i dlatego pobłogosławił jedynie swoich synów. Końcowe linie w TgN są bardzo podobne do w. 28, który zamyka cały przekaz Jakuba. Więcej dowiadujemy się na temat poglądów ówczesnej społeczności żydowskiej na temat Mesjasza, nie tylko jakie będą jego działania, ale nawet kim będzie (TgN i Tg PsJ). Ważną rolę odgrywają objaśnienia targumistów, które wypływają nie tylko z chęci wytłumaczenia Tory, ale także po to, aby była wśród ludu bardziej znana, oraz z zamiaru łączenia jej znajomości z tradycją ustnego nauczania.

Anna KUŚMIREK

Słowa kluczowe: Błogosławieństwo Jakuba, Księga Rodzaju 49, targumy, interpretacja Biblii

Keywords: Jacob's blessing, The Book of Genesis 49, targums, interpretation of the Bible

\section{"Jacob's Blessing" (Gen 49,1-28) in the Targumic Interpretation Summary}

Genesis 49 shows the scene that takes place at the deathbed of the patriarch Jacob. In the face of his upcoming death, Jacob calls all of his sons that they may listen to and accept his words of valediction. The patriarch addresses each of them individually. This piece of text serves an example of the Biblical poetry in which metaphors play an important role. In the Hebrew text there are words and phrases that raise many doubts and questions. Not only contemporary translators and biblical scholars contend with these difficulties, but ancient and medieval commentators did as well.

The Aramaic Targums testify to the early Jewish exegesis and interpretation of Gen 49. This article presents the paraphrase and discusses a few selected verses of the Aramaic version of Torah (Tg. Onq., Tg. Neof., Frgm. $T g$., $T g$. Ps.-J.). Based on the above examples, the development of principal Jewish views on eschatology (49:1-2) and of Messianic expectations in context of Jacob's blessing of the tribe of Judah (49:8-12) is portrayed. The last part of this article comprises the rendering and the meaning of the Targumic animal metaphors based on the examples of Issachar (49:14-15) and of Benjamin (49:27) that significantly differ from the Hebrew text. 